\title{
Challenges for the Newborn Following Influenza Virus Infection and Prospects for an Effective Vaccine
}

\author{
Martha A. Alexander-Miller* \\ Department of Microbiology and Immunology, Wake Forest School of Medicine, Winston-Salem, NC, United States
}

\section{OPEN ACCESS}

Edited by:

David J. Dowling,

Boston Children's Hospital,

United States

Reviewed by:

Shahram Salek-Ardakani,

Pfizer, United States

Sang-Jun $\mathrm{Ha}$

Yonsei University, South Korea

*Correspondence:

Martha A. Alexander-Miller

martha.alexander-miller@

wakehealth.edu

Specialty section:

This article was submitted to Immunological Memory, a section of the journal

Frontiers in Immunology

Received: 01 June 2020 Accepted: 18 August 2020 Published: 16 September 2020

Citation:

Alexander-Miller MA (2020) Challenges for the Newborn Following Influenza Virus Infection and Prospects for an Effective Vaccine.

Front. Immunol. 11:568651. doi: 10.3389/fimmu.2020.568651
Newborns are at significantly increased risk of severe disease following infection with influenza virus. This is the collective result of their naive status, altered immune responsiveness, and the lack of a vaccine that is effective in these individuals. Numerous studies have revealed impairments in both the innate and adaptive arms of the immune system of newborns. The consequence of these alterations is a quantitative and qualitative decrease in both antibody and $T$ cell responses. This review summarizes the hurdles newborns experience in mounting an effective response that can clear influenza virus and limit disease following infection. In addition, the challenges, as well as the opportunities, for developing vaccines that can elicit protective responses in these at risk individuals are discussed.

Keywords: newborn, vaccine, influenza, antibody, adjuvant

\section{INTRODUCTION}

Infection with influenza virus places a large burden on human health. The WHO estimates there are 290,000-650,000 influenza-associated deaths and 3-5 million cases of severe disease globally each year (https://www.who.int/news-room/fact-sheets/detail/influenza-(seasonal)). In the U.S. alone, the CDC estimated 35.5 million people experienced influenza in the 2018-19 season (www. cdc.gov/flu/about/burden/2018-2019.html). Newborns and young infants represent a particularly susceptible population for severe disease following influenza virus infection. Even in countries like the U.S., where health care resources are widely available, those under the age of 6 months are six times more likely to die as a result of influenza virus infection compared to children between the ages of 13 and 17 years (1).

While it is known that infants experience a higher rate of infection than older children, a recent study from the Influenza and Respiratory Syncytial Virus in Infants (IRIS) study suggests that our current understanding of the rate of infection significantly underestimates the burden in infants (2). Analysis of 1,934 acutely ill, non-vaccinated infants (0-11 months) enrolled during the influenza season in four countries (Albania, Jordan, Nicaragua, and the Philippines) showed 254 (13\%) were influenza virus positive by either PCR, serology, or both.

Disease states associated with influenza virus infection in infants and children include otitis media, pneumonia, myositis, and croup. The last is restricted primarily to individuals $<1$ year of age and can be life threatening. The risk of lower respiratory disease is significantly increased in children $<2$ years of age (3-7). In addition, bacterial pneumonia, which contributes to the increased lower respiratory disease in this age group, is a common complication of influenza virus infection (8). Bacterial coinfection has been shown to be a significant predictor of severe disease requiring 
admission to the pediatric intensive care unit (9). These data show that influenza virus continues to be a major health issue for newborns and young infants and establish the clear need for improved therapeutics and vaccines for this vulnerable population. Here, the underlying immune factors that contribute to the increased susceptibility to disease and the promise for the development of vaccines to protect these vulnerable individuals are discussed.

\section{THE INFANT IMMUNE SYSTEM}

The increased susceptibility to severe disease in infants following influenza virus is a result of the naïve status of newborns together with the altered responsiveness of the immune system. Much of our current understanding of the neonatal immune response comes from studies performed in the mouse or from human cord blood cells, although there is a growing body of work in the non-human primate. The results of these studies reveal alterations across the immune system, impacting both the innate and adaptive arms of the response.

The innate response is the first line of defense against an invading pathogen. Monocytes and dendritic cells (DC) play critical roles in clearance of incoming virus as well as initiation of an adaptive immune response. Activation and recruitment of these cells is often regulated by pattern recognition receptor (PRR) signaling $(10,11)$. These pathogen sensing molecules promote the activation of multiple immune cell types and as such can be critical regulators of the early immune response to influenza virus infection (12).

Analysis of DC and monocytes isolated from human cord blood revealed that these cells are decreased in their capacity to respond to pathogen associated signals, e.g., TLR agonists, compared to cells isolated from adults (13-19). PRR engagement on newborn monocytes and DC differs from adult derived cells in that it often results in the induction of a robust anti-inflammatory (e.g., IL-10) coupled with a decreased proinflammatory response (20). In mouse models, the suboptimal responsiveness of DC from neonates manifests as a decrease in the expression of costimulatory molecules and a striking reduction in IL-12 (15-17), an important signal that promotes T helper 1 (Th1) differentiation. The impaired production of this important regulatory cytokine has been associated with increased T helper 2 (Th2) differentiation and poor Th1 responses (13), the latter of which is part of an optimal influenza virus-specific response. Th2 biased differentiation appears to be the result of expression of the IL-13R $\alpha$ chain, which together with IL- $4 \mathrm{R} \alpha$ can serve as an alternative receptor for IL-4 $(21,22)$.

The decreased activation/maturation of DC in response to stimulatory signals is compounded by alteration in the number/frequency of IL-12 producing APC available for surveillance. $\mathrm{CD}^{+}$and $\mathrm{CD}^{+} 03^{+} \mathrm{DC}$ are the major producers of IL-12 in mice $(23,24)$. The correlative population in humans, $\mathrm{BDCA}^{+} \mathrm{DC}$, similarly produces high levels of IL$12(25,26)$. Newborn mice are reported to have a paucity of lymphoid tissue resident $\mathrm{CD}^{+}{ }^{\mathrm{DC}}(22)$, a DC subset that is an important contributor to the generation of a $\mathrm{CD} 8^{+} \mathrm{T}$ cell response. The alterations in DC extend to the tissue. Analysis of DC in the lungs of 1-week-old mice showed a reduced frequency of these populations as well as differences in DC subset distribution (27-29). Further, the ratio of $\mathrm{CD}_{103^{+}}$airway to $\mathrm{CD}_{1} 1 \mathrm{~b}^{+}$parenchymal $\mathrm{DC}$ was reduced in neonatal mice (28), suggesting an even greater impact on this population that serves as a potent migratory APC for driving adaptive immune responses following influenza virus infection (30). In addition to the changes in number and distribution, DC in the lungs of newborn mice are impaired in both their ability to upregulate costimulatory molecules and in antigen processing following virus infection (29).

The distribution and quantity of DC subsets in LN and lung of human neonates has been minimally explored. In a study from dos Santos et al., airway DC were reported to be very rare in infants (31). In addition, few DC expressed DC-SIGN, a C-type lectin that plays a role in uptake and TLR signaling (31). Gaining a fuller understanding of the distribution and function of DC in the newborn lung will need to be an area of high priority as we strive to meet the challenge of developing new therapeutics to support immune function following influenza virus infection in this population.

Infant mice also have a highly reduced number of plasmacytoid DC (28). While not involved in T cell activation, these cells are important sources of type I IFN, which has anti-viral activity as well as being an important regulatory cytokine for adaptive responses. Although the role of these cells in adult mice was reported to be dispensable during influenza virus infection (32), their importance to the response in infants has not been evaluated.

NK cells are another important innate immune cell for the early control of influenza virus infection $(33,34)$. NK cells mediate killing of infected cells through multiple mechanisms including antibody dependent cellular cytotoxicity, direct release of cytotoxic granules, TRAIL, and FasL. They also produce a large array of cytokines such as IL-5, IL-10, IL-13, GM-CSF, $\mathrm{TNF} \alpha, \mathrm{TGF} \beta$, and IFN $\gamma$. Surprisingly perhaps, human neonates have comparable or higher numbers and percentages of NK cells in the peripheral blood compared to adults $(35,36)$. However, these cells have a less terminally differentiated phenotype, i.e., few express CD57 (37), a marker associated with high cytotoxic and low cytokine responses. NK cells in neonates also exhibit reduced levels of CD54, suggesting impaired adherence to target cells $(38,39)$ as well as increased expression of inhibitory receptors, e.g., NKG2a (40). Thus, although they are present, their ability to contribute to viral clearance is likely impaired. As with other cell types, we have a limited understanding of lung NK cell number and function in infants. In humans, NK cells appear to be present as they were identified in the epithelial layer of human infants who had died from causes not related to pulmonary disease (31). However, how this population seeds the lungs and their ability to function in infants has not been explored.

Compounding those present in the innate arm of the immune response, there are multiple challenges on the adaptive side of the house. Some of these are a result of the innate alterations described above, e.g., cytokine production or DC maturation; this is certainly a major contributor to the propensity for 
differentiation of $\mathrm{CD}^{+} \mathrm{T}$ cells into $\mathrm{Th} 2$ cells [for review see (41)]. Biased Th2 differentiation has also been reported in human cord blood cells (42) as well as in newborn nonhuman primates (NHP) (our unpublished data). However, in addition to the regulatory signals derived from accessory cells, there are inherent attributes of adaptive immune cells that exacerbate the challenges associated with mounting a response. $\mathrm{T}$ cells from human neonates exhibit a generalized defect in responsiveness and differentiation (41,43-51), making it more difficult to activate $\mathrm{T}$ cells that do successfully engage antigenbearing DC. Reported defects include reduced levels of the signaling molecules lck and ZAP-70 (48) as well as decreased AP-1 mediated transcription (52).

As if these hurdles were not high enough, we have an increasing appreciation for the heightened $\mathrm{T}$ regulatory cell $\left(\mathrm{T}_{\text {reg }}\right)$ response that is present in newborns and young infants. Studies in human infants reveal a higher representation of Tregs in circulation (53-59), a finding also seen in NHP [(60) and manuscript in press]. This may be the result of the enhanced propensity for cells to differentiate into Tregs in these individuals $(59,61-63)$. The increase in these powerful regulators is thought to provide benefit to the newborn by dampening inflammatory responses to the establishing microbiome (64). However, the consequence of their increased frequency and activity is the potential for decreased virus-specific $\mathrm{T}$ cells in response to infection as an overly exuberant $\mathrm{T}_{\text {reg }}$ population can hamper generation of a sufficient number of effector $\mathrm{T}$ cells needed for viral clearance [e.g., $(61,65,66)]$.

Antibody responses are also significantly decreased in neonates, with reported defects in the production of high level, high affinity antibody $(41,67)$. In humans IgG production is generally weak for the first year of life $(45,68)$. Although increased relative to $\operatorname{IgG}, \operatorname{IgM}$ responses are also impaired as exemplified by RSV infection of human infants, where both IgM and IgG responses are poor (69). The altered CD4 ${ }^{+} \mathrm{T}$ cell differentiation is one likely contributor to antibody responses in newborns and young infants. Studies in newborn mice revealed IgG1 skewing, consistent with a Th2 biased response (70). Further, production of high affinity, isotype switched antibody in the germinal center relies on $\mathrm{CD} 4^{+} \mathrm{T}$ follicular helper cells (Tfh) (71-75). As with other arms of the T cell response, Tfh generation is compromised in newborns $(76,77)$. Tfh provide help to B cells through the production of cytokines, e.g., IL21 together with IL-4, IFN $\gamma$, or IL-17, as well as through the expression of CD40L $(78,79)$. Their importance for influenza vaccine responses is supported by the strong correlation between Tfh and the development of memory B cell responses in humans administered the inactivated influenza vaccine (80).

Infants are also challenged by inherent defects in B cell survival and differentiation (81). A potential contributor to the latter is the reduced expression of BCMA and BAFF-R on neonate $\mathrm{B}$ cells (82). Engagement of BAFFR or BCMA on B cells promotes survival through upregulation of anti-apoptotic bcl-2 family members together with downregulation of the proapoptotic factors bim and bad (83). Following differentiation, plasmablast survival and differentiation into long-lived antibody secreting cells depends on APRIL, the expression of which is decreased in stromal cells that reside in the bone marrow of neonates, likely hampering the sustained presence of these cells $(84,85)$. Thus, B cells encounter hurdles all along the pathway of activation, differentiation, and survival that make it harder to generate and sustain long-lived, protective antibody.

\section{THE NEWBORN IMMUNE RESPONSE TO INFLUENZA VIRUS INFECTION}

Our mechanistic understanding of the newborn response to influenza virus infection comes predominantly from analyses in mice. The earliest report of the increased disease in neonates using the mouse model comes from a study by Smith and colleagues showing newborn mice (1 day old) exhibited higher viral load and increased mortality following infection (86). Subsequent studies have made significant headway in uncovering the basis of the decreased control of influenza virus infection in this model (87-89). In a study by You et al., 7-day-old mice infected with the mouse adapted A/PR/8/34 (H1N1) (PR8) virus had a highly reduced (6-fold) $\mathrm{IFN \gamma}^{+} \mathrm{CD}^{+} \mathrm{T}$ cell response in the lungs compared to animals infected at 4 weeks of age (88). A decrease was also observed in the $\mathrm{CD} 4^{+}$compartment, albeit less than that observed for $\mathrm{CD}^{+}$cells. Interestingly, there was no evidence of an increased IL- $4^{+} \mathrm{T}$ cell response in the lungs of infant mice in this study. In addition a reduction in virus-specific $\mathrm{T}$ cells, the authors found that these effectors were reduced in their ability to clear virus as demonstrated by adoptive transfer of neonate vs. adult $\mathrm{T}$ cells (88). Increased susceptibility of newborn (here 2-day old) mice to influenza virus infection was also reported by Garvy and colleagues (87). This study focused on the capacity of $\mathrm{T}$ cells to enter into the lung and their movement to the airway. Newborns exhibited an approximately 4-day delay compared to their adult counterpart in entry of virus-specific T cells. In addition, these cells exhibited a distinct pattern of distribution in newborn mice, with a striking impairment in migration to the airway space. The failure of cells to migrate the airway correlated with a significant decrease in CXCL9 and CCL2. These data reveal that in addition to the challenges in generating an effector $\mathrm{T}$ cell response, newborns must also cope with difficulties in getting these effectors to the site of virus infection.

Recently, the overall transcriptional response in the lungs of influenza virus-infected 3-day-old mice was evaluated (89). The lungs of newborn pups showed transcriptional unresponsiveness following infection, with only a modest number of assessed genes differentially expressed as a result of influenza virus infection compared to their adult counterpart (4 vs. 55\%). Consistent with known impairments of newborn cells discussed above, the top pathways impacted were those responding to pattern recognition receptors and dendritic cell maturation. Follow-up studies to further explore these results will undoubtedly increase our understanding of the influenza virus-specific response in the newborn.

It is well-established that antibody responses are also impaired in the context of respiratory infection of human newborns and young infants (67). With that said, there is 
surprisingly little information available on the antibody response generated in newborns and young infants following influenza virus infection, even for the mouse model. However, we can infer that a likely factor that will impact antibody is the reduced $\mathrm{Tfh}$ response in newborns $(76,77)$ and the limited expression of APRIL in newborn mice given the important role of this signal in the maintenance of antibody titers in the airways and serum following influenza virus infection of adult mice (90).

Although the mouse model is highly tractable, one of the limitations of this model is the difference in immune system development at birth compared to humans (41). The immune system of newborn mice does not reflect that of higher order animals until 5-7 days following birth. In addition, the rapid maturation of the immune system in mice further complicates the study of newborn immunity. The NHP affords a useful model to mitigate these limitations. The NHP lung is also more similar in structure to humans than is the mouse lung (91). Finally, there is a high degree of similarity between the NHP and humans in the distribution and responsiveness of TLR receptors (92), in contrast to mice (14). In our studies, influenza virus infection (PR8) of newborn (6-10day old) NHP resulted in more pathology than adult NHP, even when the virus dose in the infants was decreased 5fold (60). Somewhat surprisingly, the systemic IgG response in the two age groups at d14 p.i. was similar. Whether this is the case at later times as the antibody response continues to develop is not known. In contrast, analysis of antibody in the lung revealed a reduction in virus-specific IgG antibody as well as highly reduced BALT in the lungs of newborns (60). These data suggest a model wherein an impaired local immune response in the lungs of newborns contributes to the reduced clearance and increased disease observed following influenza virus infection.

We have also evaluated the epitope specificity of the antibody response following influenza virus infection in the newborn NHP model (93). The specificity of the antibody is an important determinant of response efficacy as there are epitope-dependent differences in clearance mechanisms and cross-strain reactivity (94-99). HA represents the major target of influenza-specific antibody (100). Five neutralizing sites have been described in the globular domain of this molecule (101). In adult mice, the relative representation of antibodies directed to these sites, i.e., their pattern of immunodominance (ID), is consistent within a given mouse strain, evolves over time, and is altered by the nature of the immunizing event (i.e., vaccination vs. infection) (102). Virtually nothing is known about age related alterations in antibody ID. The ID pattern established by infection is of particular interest in newborns given the potential effects of childhood vaccination on lifelong influenza A virus (IAV) immunity as evidence suggests that the first exposure to IAV antigens can mold the lifetime response (103). Our analysis revealed altered ID patterns in the early IgM anti-HA response in newborns vs. adults that converged over time. Somewhat surprisingly the ID profiles for IgG vs. IgA differed, suggesting isotype specific regulation of ID. This study also examined the generation of antibody capable of recognizing the conserved HA stem region, a target of universal vaccine approaches. These antibodies were readily generated in newborns; similar to what is observed in adults, they are subdominant to the HA head domain $(93,104)$.

In summary, newborns face multiple challenges in combatting infection with influenza virus (Figure 1). Both the innate and adaptive arms of the response exhibit alterations that make clearance less robust. Hurdles are present at the activation/differentiation phase that occurs in the lymph node as well as the effector stage in the lung, a site where the immune system must be able to clear virus efficiently while minimizing tissue damage.

\section{INFLUENZA VACCINATION TO PROTECT NEWBORNS}

The ability to protect newborns from influenza infection through vaccination would represent a significant step forward in improving the health of this population. In considering how to harness the power of vaccines to maximize protection of newborns, there are two complementary approaches that can contribute to this goal, protection through passive transfer of vaccine-elicited maternal antibody and direct vaccination of the newborn.

Influenza vaccination for all pregnant women is the current recommendation and there is clear evidence of benefit to both mother and infant. Maternal vaccination has been reported to reduce proven influenza illness by $63 \%$ in infants up to 6 months of age and averted approximately a third of all febrile respiratory illnesses in mothers and young infants (105). Further, infants of vaccinated mothers were $45-48 \%$ less likely to have influenza hospitalizations than infants born to non-vaccinated mothers (106). Given these results, why should we not rely solely on this approach? While clearly providing increased protection for infants, the benefit of maternal antibody, as noted above, begins to wane after the first 8 weeks of life. For example, the efficacy of the trivalent inactivated influenza vaccine (TIV) administered during pregnancy for preventing PCR-confirmed influenza infection in the infants was $86 \%$ during the first 8 weeks, but decreased to $49 \%$ if considering the overall 6-month follow-up period (107). Another study reported that while $\sim 40 \%$ of infants had protective antibody levels at birth, by 3 months this had declined drastically, with only $10 \%$ retaining protective levels (108). These results make evident the critical need to develop vaccines that can initiate protective antibody responses in young infants before the loss of protection that occurs as maternal antibody wanes.

Ideally, an influenza vaccine for newborns would be capable of inducing protective responses that would be in place following a single dose of vaccine, although admittedly this is a challenging goal given the altered immune system of newborns. Given the time required for development of the peak response and the likely need for a second dose of vaccine to induce protective antibody levels, as is the case even when the current vaccine is given at 6 months of age, the initial vaccination would need to occur within the first 2 months of life in order to minimize or eliminate a window of susceptibility. 

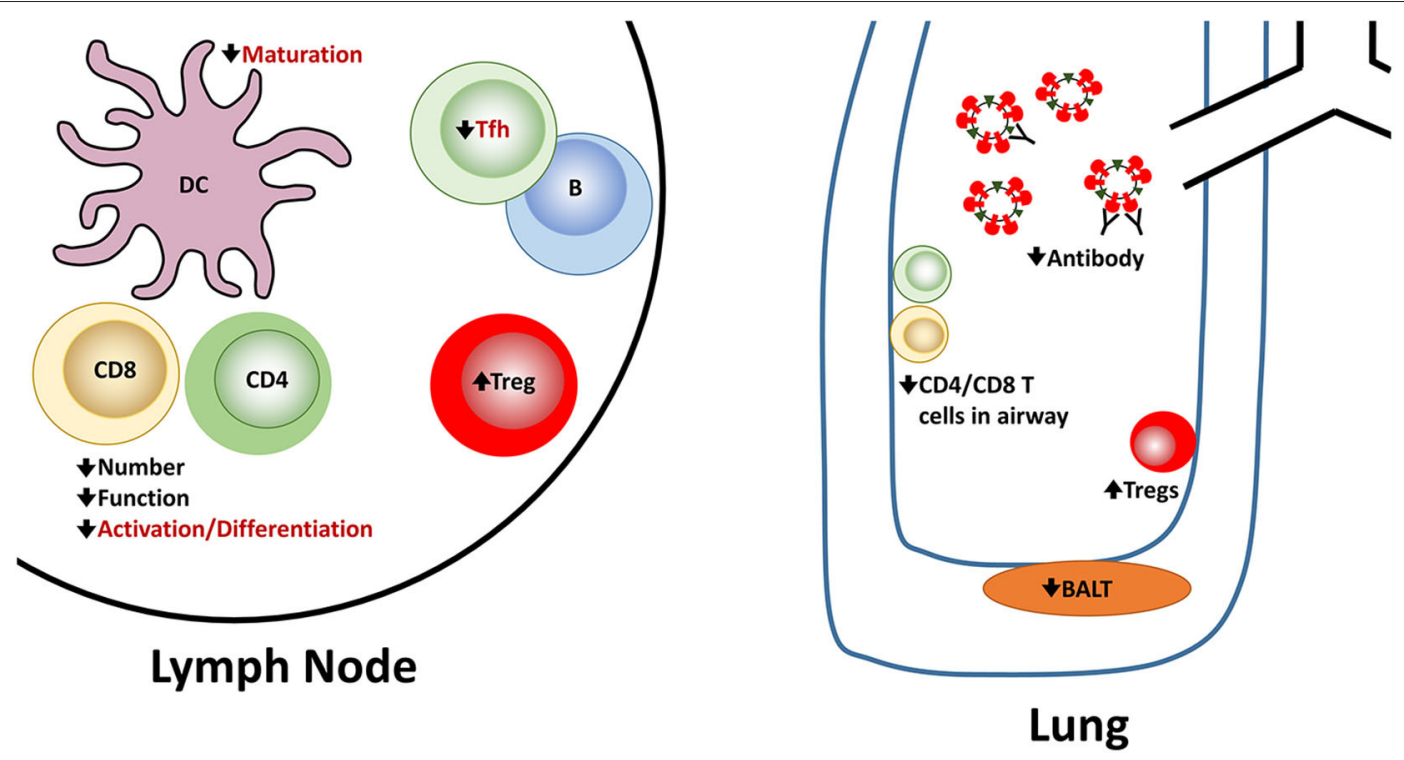

FIGURE 1 | Reported and potential alterations in the newborn immune response following influenza virus infection. Newborns encounter challenges at multiple steps in the generation of an effective immune response following influenza virus infection. A number of these have been experimentally demonstrated in newborn animal models. These are indicated in black font. There are also alterations that seem highly likely in the context of influenza virus infection based on in vitro studies or other models of newborn responses as described in the text. However, they have not been directly shown for influenza virus infection of newborns. These proposed alterations are shown in red font.

This highlights the need for improved vaccine approaches for newborns, given that these individuals do not respond effectively to the current seasonal inactivated vaccine before the age of 6 months. Previous studies reported the virtual absence of seroconversion in infants between 3 and 5 months old after a single administration of the trivalent inactivated influenza vaccine with the exception of one virus strain (A/Mississippi/11/85), which had a 40\% conversion rate for reasons that are unknown (109). While maternal antibody has the potential to inhibit vaccine responses (110), this was not the case here, as non-responding infants had influenza-specific antibody titers of $<1: 8$. A second dose resulted in a protective titer rate of approximately $29 \%$ across all strains evaluated. Not surprisingly, a correlation was observed between age and seroconversion, with older infants converting at a higher rate than younger infants (109). In a second study, conversion was assessed following two doses of vaccine, with a reported conversion rate of $32 \%$ for $\mathrm{H} 1 \mathrm{~N} 1$ and $47 \%$ for H3N2 strains (110). Mechanistic studies were not performed in these trials, so how these infants responded at the level of $\mathrm{T}$ and $\mathrm{B}$ cell activation and differentiation is not known. A review of the literature reveals a surprisingly limited amount of information in animal models to inform our mechanistic understanding of the response to the seasonal inactivated influenza vaccine in newborns vs. adults.

Given these challenges, how do we achieve the objective of protecting newborns through vaccination? One area that remains an ever present goal for increasing the efficacy of vaccines is the development of new adjuvants. Intense effort has focused on exploiting the immune stimulatory properties of TLR agonists as adjuvants, including in the infant. Among the most promising are TLR7/8 agonists. The natural ligands of TLR7 and TLR8 are guanosine- and uridine-rich ssRNA (111, 112). However, a number of small molecule mimetics have been developed that are potential vaccine adjuvants. The TLR8 agonist 3M-002 induces potent upregulation of CD40, CD80, CD83 and CD86 as well as production of the Th1-polarizing cytokine IL-12p70 in cells from neonates (113). A contributor to the effectiveness of TLR8 agonists in the context of neonate cells appears to be the resistance of this pathway to inhibition by adenosine (113), a known suppressive immune modulator in the blood of newborns (114). We have found that an inactivated vaccine comprised of the TLR7/8 agonist R848 conjugated to the influenza virion is a potent inducer of antibody and IFN $\gamma$-producing $\mathrm{T}$ cell responses in a newborn NHP model $(115,116)$. TLR2 agonists also show promise in their ability to increase activation of newborn $\mathrm{T}$ cells (117). Further, select TLR ligands can induce maturation of newborn APC, approaching the level observed in adults $(27,113$, 118). The TLR5 agonist flagellin has shown particular promise as a mucosal adjuvant for neonates in its ability to effectively induce maturation and migration of newborn lung-resident DC (27).

A strategy for further increasing the efficacy of these immune modulators is the delivery of multiple TLR agonists. Simultaneous engagement of several TLR has been shown to change dendritic cell maturation in both a qualitative and quantitative fashion $(18,119)$. $\mathrm{T}$ cells derived from human cord blood stimulated concurrently with TLR2 and TLR5 agonists underwent greater proliferation and cytokine production compared to cells stimulated with either agonist alone (117). The success of the tuberculosis vaccine (BCG: Bacille Calmette-Guerin), which is routinely delivered within $48 \mathrm{~h}$ of 


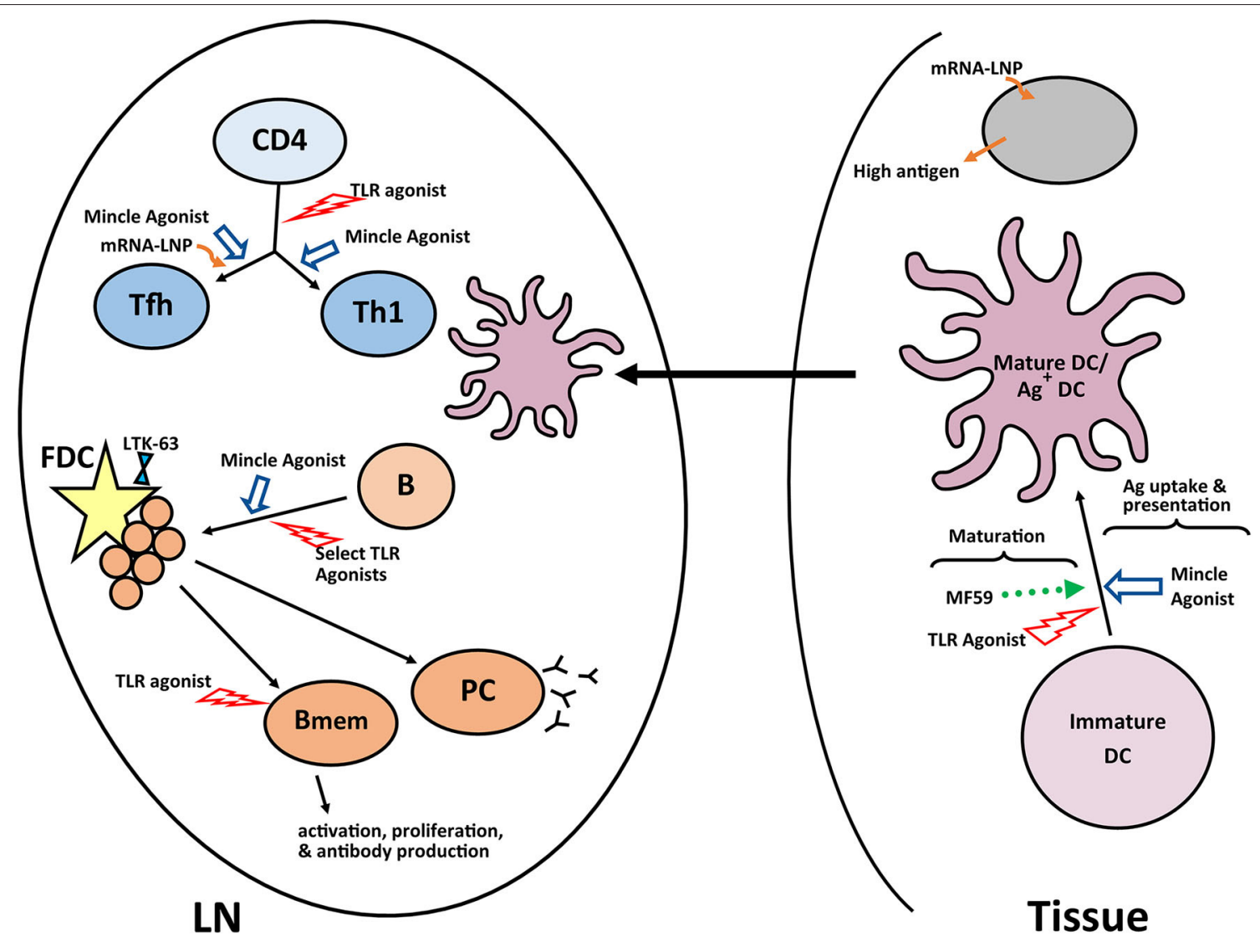

FIGURE 2 | Adjuvants and pathways reported to promote responses in newborns. A number of experimental adjuvants have been tested in the context of neonates or neonate derived cells. Some of these adjuvants impact multiple cell types, while others are more targeted. The results from these analyses suggest combinations of adjuvants may be needed to overcome the multiple impairments in the newborn immune response. A summary of a representative selection of promising adjuvants for newborns is shown. LN, lymph node; GC, germinal center; PC, plasma cell; Bmem, memory B cell; DC, dendritic cell; FDC, follicular dendritic cell.

birth, supports the utility of this strategy. BCG contains ligands for 5 distinct TLR (1, 2, 4, 6, and 9) (120) and it seems likely that the ability to induce immune responses in neonates may be due to the combined signaling following engagement of multiple TLR.

In addition to TLR agonists, other approaches are also exhibiting potential in newborns. A recent study from Hensley and colleagues reported that a nucleoside modified mRNA-lipid nanoparticle vaccine was capable of inducing prolonged germinal center formation newborns (121). The efficacy of this adjuvant has been associated with high antigen production that drives Tfh and GC B cell responses (122). Interestingly, this approach could also partially mitigate the inhibitory effects of maternal antibody (121).

Vaccination of 1 week old mice with trehalose-6,6-dibehenate (TDB), a synthetic analog of the mycobacterially-expressed trehalose-6,6-dimycolate (TDM), in combination with HA in liposomes was found to induce protection of newborn mice through increases in Tfh and generation of high affinity plasma cells (123). This is the result of signaling that is induced following binding to the C-type lectin receptor Mincle. Ligands for this PAMP detecting molecule are primarily bacterially glycolipids (124). The squalene based adjuvant MF59 has also been reported to be effective in mouse, NHP, and human neonates (125-127). Newborn (1 week old) mice vaccinated with HA and MF59 had increased influenza-specific IgG, DC maturation, and $\mathrm{CD}^{+}{ }^{+} \mathrm{T}$ cell responses. However, a potential limitation of MF59 is its failure to drive Tfh in the neonates.

The development of a robust germinal center is dependent on development of a mature follicular dendritic cell network, which occurs inefficiently in newborn mice (128). Using a tetanus toxoid conjugated polysaccharide vaccine, Jonsdottir and colleagues showed a non-toxic mutant of Escherichia coli heatlabile enterotoxin (LT-K63) could drive the maturation of the FDC network in newborn mice and that this resulted in the increased number and prolonged survival of $\mathrm{IgG}^{+}$antibody secreting cells (129). While exciting, there is recent evidence that the effects of this adjuvant can vary depending on antigen, route of delivery, and mouse strain (130). This is likely true for many of the adjuvants discussed suggesting a caution and making clear the need for empirical testing of each vaccine construct with the experimental adjuvant. A summary of the pathways successfully targeted by adjuvants in newborns is shown Figure 2. 


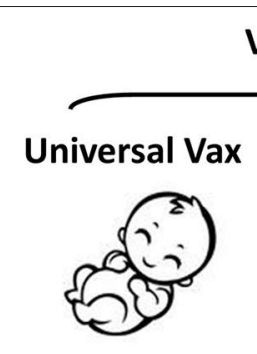

Pre-Vax

Vax \#1

No infant derived $\mathrm{Ab}$

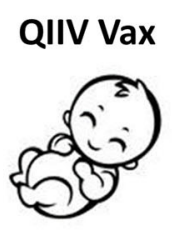

No infant

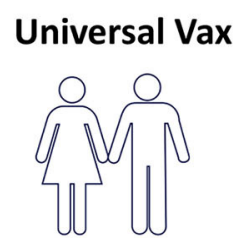

$r_{Y}^{Y} Y$

\author{
Y $\boldsymbol{\alpha}$-stem \\ Y $\boldsymbol{\alpha}$-head (QIIV strains) \\ $Y \alpha$-head (past strain)
}

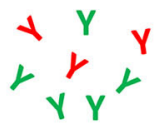

$2^{\text {nd }}$ dose
not given

${ }_{Y}^{Y}{ }^{Y}$

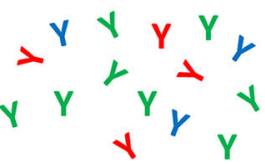

FIGURE 3 | Universal influenza vaccines as a first antigen exposure in newborns. Current influenza vaccine efforts are focused on the development of approaches that can provide broad strain recognition, i.e., a universal vaccine. These vaccines often target the conserved stem region of the HA molecule. The ability to successfully employ a universal vaccine that can work in newborns through appropriate adjuvantation would likely result in HA stem as the first influenza antigen exposure. Subsequent virus challenge should preferentially drive these universal specificities and may result in their higher representation compared to what would occur in individuals who received the stem vaccine later in life. Whether this single specificity response, e.g., stem-specific antibody, will provide adequate protection will need to be carefully assessed. QIIV, quadrivalent inactivated influenza vaccine.

\section{VACCINATION AS THE FIRST EXPOSURE TO INFLUENZA ANTIGENS}

As noted above, infants cannot receive their first dose of the seasonal inactivated influenza vaccine until they reach 6 months of age. This allows for infection to serve as the first exposure of many infants to influenza antigens. Although the priming environment for immune activation includes all of the stimulatory signals associated with infection, it comes at the cost of the potential for severe disease as described above. If we realize the goal of producing an effective influenza vaccine for use in newborns, it would become likely that the first antigen exposure for this at-risk population would come through vaccination.

A number of landmark studies have firmly established the contribution of antigenic seniority as a governing factor in driving immune responses to influenza vaccination or infection [for review see (131)]. The notion of antigenic seniority states that strains encountered early in childhood establish a position of seniority, such that these responses are preferentially boosted following encounter with alternative strains over a lifetime. This then shapes an individual's response to a given strain confronted later in life and over time, there is an accumulation of antibody and memory B cells specific for childhood strains.

Adding an additional layer of complexity to this process, in mice there is evidence that the immune response primed by vaccination vs. infection is altered (102). Using a panel of viruses that individually expresses each of the five neutralizing epitopes identified in the HA head, Angeletti et al., showed that the pattern of immunodominance, i.e., the representation of each of the HA epitopes in the antibody repertoire, was distinct following infection vs. vaccination (102). This has the potential to functionally impact the response as the representation of antibodies directed to individual epitopes can impact how the virus is cleared, i.e., neutralization vs. antibody dependent cellular cytotoxicity (ADCC). While, the ability of vaccination vs. infection to alter dominance patterns in newborns has not been tested, the results suggest an intriguing possibility that newborn priming of influenza-specific responses by vaccination vs. infection may result in differences in the representation of antibodies to these individual epitopes. This may in turn alter the array of mechanisms available for combating infection as well as the specificity of antibodies boosted 
following subsequent encounter with viruses or vaccines in the following years.

The concept of antigenic seniority has taken on added importance in newborn vaccination in light of recent efforts directed toward development of a universal vaccine approach. A vaccine that can protect from drifted strains, i.e., those that have point mutations in the globular head domain of the HA molecule, that circulate in subsequent seasons would decrease the need for yearly reformulation and delivery of the vaccine. Such a vaccine also has the potential to provide protection from pandemic strains. Currently universal vaccine development is primarily focused on driving antibody responses to the highly conserved stem region of HA [there are multiple excellent reviews on this effort, e.g., $(95,132-134)]$. Such a vaccine is now being tested in adults in clinical trials (NCT03814720, www.clinicaltrials.gov).

Is this approach feasible in newborns? The answer may be yes based on our recent studies of newborn NHP in which we observed a robust response to the HA stem region following infection (93). These data suggest the newborn B cell repertoire has the potential mount this response. Further, the avidity of the HA stem-specific antibodies produced appears to be on par with antibodies binding to other epitopes (93). Our understanding of antigenic seniority would indicate that priming the newborn response with an HA stem construct would be of significant benefit. Pre-clinical studies performed in adult mice and ferrets vaccinated with a stem bearing nanoparticle construct resulted in generation of broadly crossreactive antibodies (135). These antibodies could completely protect mice and partially protect ferrets against a lethal heterosubtypic H5N1 influenza virus challenge (135). We would expect that antibody responses generated by an HA stem vaccine would allow for preferential activation and boosting of these broadly protective antibody responses following infection or subsequent vaccination (Figure 3 ). The response will likely differ in human newborns vs. adults, as the latter already has a population of memory cells that can respond to the vaccine that will undergo selective boosting. Priming responses from a naive repertoire in the newborn would leave the infant with a single antibody specificity. While stem-specific antibodies should provide benefit through broad strain recognition, it is critical that we understand more fully the protective capacity of such a vaccine. In addition, how this universal response would impact subsequent responses to the head region of HA or other viral proteins needs to be addressed. Answering these questions

\section{REFERENCES}

1. Shang M, Blanton L, Brammer L, Olsen SJ, Fry AM. Influenza-associated pediatric deaths in the United States, 2010-2016. Pediatrics. (2018) 141:e20172918. doi: 10.1542/peds.2017-2918

2. Thompson MG, Levine MZ, Bino S, Hunt DR, Al-Sanouri TM, Simoes EAF, et al. Underdetection of laboratory-confirmed influenza-associated hospital admissions among infants: a multicentre, prospective study. Lancet Child Adolesc Health. (2019) 3:781-94. doi: 10.1016/S2352-4642(19)30246-9

3. Peltola V, Heikkinen T, Ruuskanen O. Clinical courses of croup caused by influenza and parainfluenza viruses. Pediatr Infect Dis J. (2002) 21:768. doi: 10.1097/00006454-200201000-00020 will be a critical step in advancing universal vaccines for use in infants.

\section{CONCLUDING REMARKS}

Newborn vulnerability to severe disease following influenza virus infection is a significant public health concern. Current influenza vaccines are inadequate for eliciting protective responses in these at-risk individuals and while maternal antibody can provide benefit, waning antibody levels will leave the infant increasingly unprotected in the months following birth. The time necessary for a prime and boost-approach to achieve protective antibody levels necessitates early delivery of the first vaccine dose to limit the window of susceptibility to infection that will occur as maternal antibody decreases and infant immunity develops. While a number of experimental adjuvants show promise in newborns, a more in depth understanding of the newborn immune system will be critical to the development of effective adjuvants and vaccine delivery approaches. This will be facilitated by use of models that most faithfully reflect the human newborn immune system coupled with our increasing ability to assess human newborns as a result of technological advances that maximize the information that can be gained with the limited samples accessible from these individuals. While the challenges are significant, they are not insurmountable, and we are continually nearing the goal of developing a vaccine that can limit influenza virus infection and disease in newborns.

\section{AUTHOR CONTRIBUTIONS}

MA-M wrote and edited the manuscript.

\section{FUNDING}

This work was supported by Grant R01AI098339 (to MA-M), R21AI137741 (to MA-M), R01AI146059 (to MA-M), and by funds provided through the Dolores G. Evans, Ph.D. Chair in Microbiology and Immunology.

\section{ACKNOWLEDGMENTS}

I am grateful to Elene Clemens and Kali Crofts for helpful comments on the review and to Corinne Miller for assistance with the figures.
4. Neuzil KM, Mellen BG, Wright PF, Mitchel EF Jr, Griffin MR. The effect of influenza on hospitalizations, outpatient visits, and courses of antibiotics in children. $N$ Engl J Med. (2000) 342:225-31. doi: 10.1056/NEJM200001273420401

5. Neuzil KM, Zhu Y, Griffin MR, Edwards KM, Thompson JM, Tollefson SJ, et al. Burden of interpandemic influenza in children younger than 5 years: a 25-year prospective study. J Infect Dis. (2002) 185:14752. doi: $10.1086 / 338363$

6. Meier CR, Napalkov PN, Wegmuller Y, Jefferson T, Jick H. Population-based study on incidence, risk factors, clinical complications and drug utilisation associated with influenza in the United Kingdom. Eur J Clin Microbiol Infect Dis. (2000) 19:834-42. doi: 10.1007/s100960000376 
7. Izurieta HS, Thompson WW, Kramarz P, Shay DK, Davis RL, DeStefano $\mathrm{F}$, et al. Influenza and the rates of hospitalization for respiratory disease among infants and young children. N Engl J Med. (2000) 342:2329. doi: 10.1056/NEJM200001273420402

8. Munoz FM. Influenza virus infection in infancy and early childhood. Paediatr Respir Rev. (2003) 4:99-104. doi: 10.1016/S1526-0542(03)00027-7

9. Khandaker G, Zurynski Y, Ridley G, Buttery J, Marshall H, Richmond $\mathrm{PC}$, et al. Clinical epidemiology and predictors of outcome in children hospitalised with influenza A(H1N1)pdm09 in 2009: a prospective national study. Influenza Other Respir Viruses. (2014) 8:636-45. doi: 10.1111/irv.12286

10. Takeuchi O, Akira S. Innate immunity to virus infection. Immunol Rev. (2009) 227:75-86. doi: 10.1111/j.1600-065X.2008.00737.x

11. Jensen S, Thomsen AR. Sensing of RNA viruses: a review of innate immune receptors involved in recognizing RNA virus invasion. J Virol. (2012) 86:2900-10. doi: 10.1128/JVI.05738-11

12. Jung HE, Lee HK. Host protective immune responses against influenza A Virus infection. Viruses. (2020) 12:504. doi: 10.3390/v12050504

13. Zaghouani H, Hoeman CM, Adkins B. Neonatal immunity: faulty T-helpers and the shortcomings of dendritic cells. Trends Immunol. (2009) 30:58591. doi: 10.1016/j.it.2009.09.002

14. Willems F, Vollstedt S, Suter M. Phenotype and function of neonatal DC. Eur J Immunol. (2009) 39:26-35. doi: 10.1002/eji.200838391

15. Goriely S, Vincart B, Stordeur P, Vekemans J, Willems F, Goldman $\mathrm{M}$, et al. Deficient IL-12(p35) gene expression by dendritic cells derived from neonatal monocytes. J Immunol. (2001) 166:2141-6. doi: 10.4049/jimmunol.166.3.2141

16. Langrish CL, Buddle JC, Thrasher AJ, Goldblatt D. Neonatal dendritic cells are intrinsically biased against Th-1 immune responses. Clin Exp Immunol. (2002) 128:118-23. doi: 10.1046/j.1365-2249.2002.01817.x

17. De Wit D, Tonon S, Olislagers V, Goriely S, Boutriaux M, Goldman $\mathrm{M}$, et al. Impaired responses to toll-like receptor 4 and toll-like receptor 3 ligands in human cord blood. J Autoimmun. (2003) 21:27781. doi: 10.1016/j.jaut.2003.08.003

18. Krumbiegel D, Zepp F, Meyer CU. Combined Toll-like receptor agonists synergistically increase production of inflammatory cytokines in human neonatal dendritic cells. Hum Immunol. (2007) 68:813-22. doi: 10.1016/j.humimm.2007.08.001

19. Marodi L. Innate cellular immune responses in newborns. Clin Immunol. (2006) 118:137-44. doi: 10.1016/j.clim.2005.10.012

20. Kollmann TR, Crabtree J, Rein-Weston A, Blimkie D, Thommai F, Wang XY, et al. Neonatal innate TLR-mediated responses are distinct from those of adults. J Immunol. (2009) 183:7150-60. doi: 10.4049/jimmunol.0901481

21. Li L, Lee HH, Bell JJ, Gregg RK, Ellis JS, Gessner A, et al. IL4 utilizes an alternative receptor to drive apoptosis of Th1 cells and skews neonatal immunity toward Th2. Immunity. (2004) 20:42940. doi: 10.1016/S1074-7613(04)00072-X

22. Lee HH, Hoeman CM, Hardaway JC, Guloglu FB, Ellis JS, Jain R, et al. Delayed maturation of an IL-12-producing dendritic cell subset explains the early Th2 bias in neonatal immunity. J Exp Med. (2008) 205:226980. doi: $10.1084 /$ jem.20071371

23. Hochrein H, Shortman K, Vremec D, Scott B, Hertzog P, O'Keeffe M. Differential production of IL-12, IFN-alpha, and IFN-gamma by mouse dendritic cell subsets. J Immunol. (2001) 166:5448-55. doi: 10.4049/jimmunol.166.9.5448

24. Martinez-Lopez M, Iborra S, Conde-Garrosa R, Sancho D. Batf3-dependent $\mathrm{CD}_{103}{ }^{+}$dendritic cells are major producers of IL-12 that drive local Th1 immunity against Leishmania major infection in mice. Eur J Immunol. (2015) 45:119-29. doi: 10.1002/eji.201444651

25. Villadangos JA, Shortman K. Found in translation: the human equivalent of mouse $\mathrm{CD}^{+}$dendritic cells. J Exp Med. (2010) 207:1131-4. doi: 10.1084/jem.20100985

26. Jongbloed SL, Kassianos AJ, McDonald KJ, Clark GJ, Ju X, Angel CE, et al. Human $\mathrm{CD}_{141^{+}}(\mathrm{BDCA}-3)^{+}$dendritic cells (DCs) represent a unique myeloid DC subset that cross-presents necrotic cell antigens. J Exp Med. (2010) 207:1247-60. doi: 10.1084/jem.20092140

27. Sharma P, Levy O, Dowling DJ. The TLR5 agonist flagellin shapes phenotypical and functional activation of lung mucosal antigen presenting cells in neonatal mice. Front Immunol. (2020) 11:171. doi: 10.3389/fimmu.2020.00171

28. Roux X, Remot A, Petit-Camurdan A, Nahori MA, Kiefer-Biasizzo $H$, Marchal G, et al. Neonatal lung immune responses show a shift of cytokines and transcription factors toward Th2 and a deficit in conventional and plasmacytoid dendritic cells. Eur J Immunol. (2011) 41:2852-61. doi: 10.1002/eji.201041224

29. Ruckwardt TJ, Malloy AM, Morabito KM, Graham BS. Quantitative and qualitative deficits in neonatal lung-migratory dendritic cells impact the generation of the $\mathrm{CD}^{+} \mathrm{T}$ cell response. PLoS Pathog. (2014) 10:e1003934. doi: 10.1371/journal.ppat.1003934

30. Kim TS, Braciale TJ. Respiratory dendritic cell subsets differ in their capacity to support the induction of virus-specific cytotoxic $\mathrm{CD} 8^{+} \mathrm{T}$ cell responses. PLoS ONE. (2009) 4:e4204. doi: 10.1371/journal.pone.0004204

31. dos Santos AB, Binoki D, Silva LF, de Araujo BB, Otter ID, Annoni R, et al. Immune cell profile in infants' lung tissue. Ann Anat. (2013) 195:596604. doi: 10.1016/j.aanat.2013.05.003

32. Wolf AI, Buehler D, Hensley SE, Cavanagh LL, Wherry EJ, Kastner P, et al. Plasmacytoid dendritic cells are dispensable during primary influenza virus infection. J Immunol. (2009) 182:871-9. doi: 10.4049/jimmunol.182.2.871

33. Stein-Streilein J, Guffee J. In vivo treatment of mice and hamsters with antibodies to asialo GM1 increases morbidity and mortality to pulmonary influenza infection. J Immunol. (1986) 136:1435-41.

34. Gazit R, Gruda R, Elboim M, Arnon TI, Katz G, Achdout H, et al. Lethal influenza infection in the absence of the natural killer cell receptor gene Ncr1. Nat Immunol. (2006) 7:517-23. doi: 10.1038/ni1322

35. Chin TW, Ank BJ, Murakami D, Gill M, Spina C, Strom S, et al. Cytotoxic studies in human newborns: lessened allogeneic cellinduced (augmented) cytotoxicity but strong lymphokine-activated cytotoxicity of cord mononuclear cells. Cell Immunol. (1986) 103:241-51. doi: 10.1016/0008-8749(86)90087-0

36. Peoples JD, Cheung S, Nesin M, Lin H, Tatad AM, Hoang D, et al. Neonatal cord blood subsets and cytokine response to bacterial antigens. Am J Perinatol. (2009) 26:647-57. doi: 10.1055/s-0029-1220788

37. Tanaka H, Kai S, Yamaguchi M, Misawa M, Fujimori Y, Yamamoto M, et al. Analysis of natural killer (NK) cell activity and adhesion molecules on NK cells from umbilical cord blood. Eur J Haematol. (2003) 71:2938. doi: 10.1034/j.1600-0609.2003.00081.x

38. Lin SJ, Kuo ML. Effect of cyclosporin A on interleukin-15-activated umbilical cord blood natural killer cell function. Cytotherapy. (2008) 10:397405. doi: 10.1080/14653240802129885

39. Lin SJ, Yan DC. ICAM-1 (CD54) expression on $\mathrm{T}$ lymphocytes and natural killer cells from umbilical cord blood: regulation with interleukin-12 and interleukin-15. Cytokines Cell Mol Ther. (2000) 6:161-4. doi: $10.1080 / \mathrm{mccm} .6 .4 .161 .164$

40. Wang Y, Xu H, Zheng X, Wei H, Sun R, Tian Z. High expression of NKG2A/CD94 and low expression of granzyme B are associated with reduced cord blood NK cell activity. Cell Mol Immunol. (2007) 4:377-82.

41. Adkins B, Leclerc C, Marshall-Clarke S. Neonatal adaptive immunity comes of age. Nat Rev Immunol. (2004) 4:553-64. doi: 10.1038/nri1394

42. Naderi N, Pourfathollah AA, Alimoghaddam K, Moazzeni SM. Cord blood dendritic cells prevent the differentiation of naive T-helper cells towards Th1 irrespective of their subtype. Clin Exp Med. (2009) 9:2936. doi: 10.1007/s10238-008-0020-2

43. Winkler S, Willheim M, Baier K, Schmid D, Aichelburg A, Graninger W, et al. Frequency of cytokine-producing $\mathrm{T}$ cells in patients of different age groups with Plasmodium falciparum malaria. J Infect Dis. (1999) 179:20916. doi: $10.1086 / 314571$

44. Xainli J, Baisor M, Kastens W, Bockarie M, Adams JH, King CL. Age-dependent cellular immune responses to Plasmodium vivax Duffy binding protein in humans. J Immunol. (2002) 169:3200-7. doi: 10.4049/jimmunol.169.6.3200

45. Randolph DA. The neonatal adaptive immune system. NeoReviews. (2005) 6:e454-62. doi: 10.1542/neo.6-10-e454

46. Zhao Y, Dai ZP, Lv P, Gao XM. Phenotypic and functional analysis of human $\mathrm{T}$ lymphocytes in early second- and third-trimester fetuses. Clin Exp Immunol. (2002) 129:302-8. doi: 10.1046/j.1365-2249.2002.0 1920.x 
47. Clerici M, DePalma L, Roilides E, Baker R, Shearer GM. Analysis of T helper and antigen-presenting cell functions in cord blood and peripheral blood leukocytes from healthy children of different ages. J Clin Invest. (1993) 91:2829-36. doi: 10.1172/JCI116526

48. Miscia S, Di Baldassarre A, Sabatino G, Bonvini E, Rana RA, Vitale M, et al. Inefficient phospholipase $\mathrm{C}$ activation and reduced Lck expression characterize the signaling defect of umbilical cord T lymphocytes. J Immunol. (1999) 163:2416-24.

49. Harris DT, Schumacher MJ, Locascio J, Besencon FJ, Olson GB, DeLuca D, et al. Phenotypic and functional immaturity of human umbilical cord blood T lymphocytes. Proc Natl Acad Sci USA. (1992) 89:1000610. doi: 10.1073/pnas.89.21.10006

50. Chen L, Cohen AC, Lewis DB. Impaired allogeneic activation and T-helper 1 differentiation of human cord blood naive CD4 T cells. Biol Blood Marrow Transplant. (2006) 12:160-71. doi: 10.1016/j.bbmt.2005.10.027

51. Nonoyama S, Penix LA, Edwards CP, Lewis DB, Ito S, Aruffo A, et al. Diminished expression of CD40 ligand by activated neonatal T cells. J Clin Invest. (1995) 95:66-75. doi: 10.1172/JCI117677

52. Palin AC, Ramachandran V, Acharya S, Lewis DB. Human neonatal naive $\mathrm{CD}^{+} \mathrm{T}$ cells have enhanced activation-dependent signaling regulated by the microRNA miR-181a. J Immunol. (2013) 190:268291. doi: 10.4049/jimmunol.1202534

53. Michaelsson J, Mold JE, McCune JM, Nixon DF. Regulation of T cell responses in the developing human fetus. J Immunol. (2006) 176:57418. doi: 10.4049/jimmunol.176.10.5741

54. Nettenstrom L, Alderson K, Raschke EE, Evans MD, Sondel PM, Olek S, et al. An optimized multi-parameter flow cytometry protocol for human $\mathrm{T}$ regulatory cell analysis on fresh and viably frozen cells, correlation with epigenetic analysis, and comparison of cord and adult blood. J Immunol Methods. (2013) 387:81-8. doi: 10.1016/j.jim.2012.09.014

55. Renno C, Nadaf MI, Zago CA, Carneiro-Sampaio M, Palmeira P. Healthy preterm newborns show an increased frequency of $\mathrm{CD}^{+} \mathrm{CD} 25^{\text {high }}$ $\mathrm{CD}_{12} 7^{\text {low }} \mathrm{FOXP}^{+}$regulatory $\mathrm{T}$ cells with a naive phenotype and high expression of gut-homing receptors. Scand J Immunol. (2016) 83:44555. doi: $10.1111 /$ sji.12435

56. Grindebacke H, Stenstad H, Quiding-Jarbrink M, Waldenstrom J, Adlerberth I, Wold AE, et al. Dynamic development of homing receptor expression and memory cell differentiation of infant $\mathrm{CD} 4{ }^{+} \mathrm{CD} 25^{\text {high }}$ regulatory $\mathrm{T}$ cells. J Immunol. (2009) 183:4360-70. doi: 10.4049/jimmunol.0901091

57. van Gent R, van Tilburg CM, Nibbelke EE, Otto SA, Gaiser JF, JanssensKorpela PL, et al. Refined characterization and reference values of the pediatric T- and B-cell compartments. Clin Immunol. (2009) 133:95107. doi: 10.1016/j.clim.2009.05.020

58. Prabhu SB, Rathore DK, Nair D, Chaudhary A, Raza S, Kanodia $\mathrm{P}$, et al. Comparison of human neonatal and adult blood leukocyte subset composition phenotypes. PLoS ONE. (2016) 11:e0162242. doi: 10.1371/journal.pone.0162242

59. Hayakawa S, Ohno N, Okada S, Kobayashi M. Significant augmentation of regulatory $\mathrm{T}$ cell numbers occurs during the early neonatal period. Clin Exp Immunol. (2017) 190:268-79. doi: 10.1111/cei.13008

60. Holbrook BC, Hayward SL, Blevins LK, Kock N, Aycock T, Parks GD, et al. Nonhuman primate infants have an impaired respiratory but not systemic IgG antibody response following influenza virus infection. Virology. (2015) 476:124-33. doi: 10.1016/j.virol.2014.12.007

61. Fernandez MA, Puttur FK, Wang YM, Howden W, Alexander SI, Jones CA. $\mathrm{T}$ regulatory cells contribute to the attenuated primary $\mathrm{CD} 8^{+}$and $\mathrm{CD} 4^{+} \mathrm{T}$ cell responses to herpes simplex virus type 2 in neonatal mice. J Immunol. (2008) 180:1556-64. doi: 10.4049/jimmunol.180.3.1556

62. Wang G, Miyahara Y, Guo Z, Khattar M, Stepkowski SM, Chen W. "Default" generation of neonatal regulatory T cells. J Immunol. (2010) 185:71-8. doi: 10.4049/jimmunol.0903806

63. Ndure J, Flanagan KL. Targeting regulatory $\mathrm{T}$ cells to improve vaccine immunogenicity in early life. Front Microbiol. (2014) 5:477. doi: 10.3389/fmicb.2014.00477

64. Kamada N, Nunez G. Role of the gut microbiota in the development and function of lymphoid cells. J Immunol. (2013) 190:1389-95. doi: 10.4049/jimmunol.1203100
65. Chappert P, Leboeuf M, Rameau P, Lalfer M, Desbois S, Liblau RS, et al. Antigen-specific Treg impair CD8 ${ }^{+}$T-cell priming by blocking early T-cell expansion. Eur J Immunol. (2010) 40:339-50. doi: 10.1002/eji.200839107

66. Haeryfar SM, DiPaolo RJ, Tscharke DC, Bennink JR, Yewdell JW. Regulatory $\mathrm{T}$ cells suppress $\mathrm{CD} 8{ }^{+} \mathrm{T}$ cell responses induced by direct priming and crosspriming and moderate immunodominance disparities. J Immunol. (2005) 174:3344-51. doi: 10.4049/jimmunol.174.6.3344

67. Crowe JE Jr, Williams JV. Immunology of viral respiratory tract infection in infancy. Paediatr Respir Rev. (2003) 4:1129. doi: 10.1016/S1526-0542(03)00033-2

68. Gans H, DeHovitz R, Forghani B, Beeler J, Maldonado Y, Arvin AM. Measles and mumps vaccination as a model to investigate the developing immune system: passive and active immunity during the first year of life. Vaccine. (2003) 21:3398-405. doi: 10.1016/S0264-410X(03)00341-4

69. Brandenburg AH, Groen J, van Steensel-Moll HA, Claas EC, Rothbarth PH, Neijens HJ, et al. Respiratory syncytial virus specific serum antibodies in infants under six months of age: limited serological response upon infection. J Med Virol. (1997) 52:97104. doi: 10.1002/(sici)1096-9071(199705)52:1 < 97::aid-jmv16>3.0.co;2-y

70. Tregoning JS, Wang BL, McDonald JU, Yamaguchi Y, Harker JA, Goritzka $\mathrm{M}$, et al. Neonatal antibody responses are attenuated by interferon-gamma produced by NK and T cells during RSV infection. Proc Natl Acad Sci USA. (2013) 110:5576-81. doi: 10.1073/pnas.1214247110

71. Linterman MA, Hill DL. Can follicular helper T cells be targeted to improve vaccine efficacy? F1000Res. (2016) 5. doi: 10.12688/f1000research.7388.1

72. Butler NS, Kulu DI. The regulation of $\mathrm{T}$ follicular helper responses during infection. Curr Opin Immunol. (2015) 34:68-74. doi: 10.1016/j.coi.2015.02.007

73. Xu H, Wang X, Lackner AA, Veazey RS. PD-1 ${ }^{\text {HIGH }}$ Follicular CD4 T helper cell subsets residing in lymph node germinal centers correlate with B cell maturation and IgG production in rhesus macaques. Front Immunol. (2014) 5:85. doi: 10.3389 /fimmu.2014.00085

74. Zhang Y, Garcia-Ibanez L, Toellner KM. Regulation of germinal center B-cell differentiation. Immunol Rev. (2016) 270:8-19. doi: 10.1111/imr.12396

75. Stebegg M, Kumar SD, Silva-Cayetano A, Fonseca VR, Linterman MA, Graca L. Regulation of the germinal center response. Front Immunol. (2018) 9:2469. doi: 10.3389/fimmu.2018.02469

76. Debock I, Jaworski K, Chadlaoui H, Delbauve S, Passon N, Twyffels L, et al. Neonatal follicular Th cell responses are impaired and modulated by IL-4. J Immunol. (2013) 191:1231-9. doi: 10.4049/jimmunol.1203288

77. Mastelic B, Kamath AT, Fontannaz P, Tougne C, Rochat AF, Belnoue E, et al. Environmental and $\mathrm{T}$ cell-intrinsic factors limit the expansion of neonatal follicular $\mathrm{T}$ helper cells but may be circumvented by specific adjuvants. $J$ Immunol. (2012) 189:5764-72. doi: 10.4049/jimmunol.1201143

78. Shulman Z, Gitlin AD, Weinstein JS, Lainez B, Esplugues E, Flavell RA, et al. Dynamic signaling by $\mathrm{T}$ follicular helper cells during germinal center B cell selection. Science. (2014) 345:1058-62. doi: 10.1126/science.1257861

79. Liu D, Xu H, Shih C, Wan Z, Ma X, Ma W, et al. T-B-cell entanglement and ICOSL-driven feed-forward regulation of germinal centre reaction. Nature. (2015) 517:214-8. doi: 10.1038/nature13803

80. Koutsakos M, Wheatley AK, Loh L, Clemens EB, Sant S, Nussing S, et al. Circulating TFH cells, serological memory, and tissue compartmentalization shape human influenza-specific B cell immunity. Sci Transl Med. (2018) 10. doi: 10.1126/scitranslmed.aan 8405

81. Siegrist CA. The challenges of vaccine responses in early life: selected examples. J Comp Pathol. (2007) 137 Suppl 1:S4-9. doi: 10.1016/j.jcpa.2007.04.004

82. Kaur K, Chowdhury S, Greenspan NS, Schreiber JR. Decreased expression of tumor necrosis factor family receptors involved in humoral immune responses in preterm neonates. Blood. (2007) 110:2948-54. doi: 10.1182/blood-2007-01-069245

83. Rickert RC, Jellusova J, Miletic AV. Signaling by the tumor necrosis factor receptor superfamily in B-cell biology and disease. Immunol Rev. (2011) 244:115-33. doi: 10.1111/j.1600-065X.2011.01067.x

84. Belnoue E, Pihlgren M, McGaha TL, Tougne C, Rochat AF, Bossen C, et al. APRIL is critical for plasmablast survival in the bone marrow and poorly expressed by early-life bone marrow stromal cells. Blood. (2008) 111:2755-64. doi: 10.1182/blood-2007-09-110858 
85. Pihlgren M, Friedli M, Tougne C, Rochat AF, Lambert PH, Siegrist CA. Reduced ability of neonatal and early-life bone marrow stromal cells to support plasmablast survival. I Immunol. (2006) 176:16572. doi: 10.4049/jimmunol.176.1.165

86. Collie $\mathrm{MH}$, Sweet $\mathrm{C}$, Smith H. Infection of neonatal and adult mice with non-passaged influenza viruses. Brief report. Arch Virol. (1980) 65:7781. doi: 10.1007/BF01340544

87. Lines JL, Hoskins S, Hollifield M, Cauley LS, Garvy BA. The migration of T cells in response to influenza virus is altered in neonatal mice. J Immunol. (2010) 185:2980-8. doi: 10.4049/jimmunol.0903075

88. You D, Ripple M, Balakrishna S, Troxclair D, Sandquist D, Ding L, et al. Inchoate $\mathrm{CD}^{+} \mathrm{T}$ cell responses in neonatal mice permit influenzainduced persistent pulmonary dysfunction. J Immunol. (2008) 181:348694. doi: 10.4049/jimmunol.181.5.3486

89. Kumova OK, Fike AJ, Thayer JL, Nguyen LT, Mell JC, Pascasio J, et al. Lung transcriptional unresponsiveness and loss of early influenza virus control in infected neonates is prevented by intranasal Lactobacillus rhamnosus GG. PLoS Pathog. (2019) 15:e1008072. doi: 10.1371/journal.ppat.1008072

90. Wolf AI, Mozdzanowska K, Quinn WJ 3rd, Metzgar M, Williams KL, Caton AJ, et al. Protective antiviral antibody responses in a mouse model of influenza virus infection require TACI. J Clin Invest. (2011) 121:395464. doi: 10.1172/JCI57362

91. Irvin CG, Bates JH. Measuring the lung function in the mouse: the challenge of size. Respir Res. (2003) 4:4. doi: 10.1186/rr199

92. Ketloy C, Engering A, Srichairatanakul U, Limsalakpetch A, Yongvanitchit K, Pichyangkul S, et al. Expression and function of Toll-like receptors on dendritic cells and other antigen presenting cells from non-human primates. Vet Immunol Immunopathol. (2008) 125:18-30. doi: 10.1016/j.vetimm.2008.05.001

93. Clemens E, Angeletti D, Holbrook BC, Kanekiyo M, Jorgensen MJ, Graham BS, et al. Influenza-infected newborn and adult monkeys exhibit a strong primary antibody response to hemagglutinin stem. JCI Insight. (2020) 5:e135449.doi: 10.1172/jci.insight.135449

94. Altman MO, Angeletti D, Yewdell JW. Antibody immunodominance: the key to understanding influenza virus antigenic drift. Viral Immunol. (2018) 31:142-9. doi: 10.1089/vim.2017.0129

95. Angeletti D, Yewdell JW. Understanding and manipulating viral immunity: antibody immunodominance enters center stage. Trends Immunol. (2018) 39:549-61. doi: 10.1016/j.it.2018.04.008

96. Andrews SF, Huang Y, Kaur K, Popova LI, Ho IY, Pauli NT, et al. Immune history profoundly affects broadly protective B cell responses to influenza. Sci Transl Med. (2015) 7:316ra192. doi: 10.1126/scitranslmed.aad0522

97. He W, Tan GS, Mullarkey CE, Lee AJ, Lam MM, Krammer F, et al. Epitope specificity plays a critical role in regulating antibody-dependent cellmediated cytotoxicity against influenza A virus. Proc Natl Acad Sci USA. (2016) 113:11931-6. doi: 10.1073/pnas.1609316113

98. Wrammert J, Koutsonanos D, Li GM, Edupuganti S, Sui J, Morrissey M, et al. Broadly cross-reactive antibodies dominate the human B cell response against 2009 pandemic H1N1 influenza virus infection. J Exp Med. (2011) 208:181-93. doi: 10.1084/jem.20101352

99. Kosik I, Yewdell JW. Influenza A virus hemagglutinin specific antibodies interfere with virion neuraminidase activity via two distinct mechanisms. Virology. (2017) 500:178-83. doi: 10.1016/j.virol.2016.10.024

100. Chen YQ, Wohlbold TJ, Zheng NY, Huang M, Huang Y, Neu KE, et al. Influenza infection in humans induces broadly cross-reactive and protective neuraminidase-reactive antibodies. Cell. (2018) 173:41729.e10. doi: 10.1016/j.cell.2018.03.030

101. Caton AJ, Brownlee GG, Yewdell JW, Gerhard W. The antigenic structure of the influenza virus A/PR/8/34 hemagglutinin (H1 subtype). Cell. (1982) 31:417-27. doi: 10.1016/0092-8674(82)90135-0

102. Angeletti D, Gibbs JS, Angel M, Kosik I, Hickman HD, Frank GM, et al. Defining B cell immunodominance to viruses. Nat Immunol. (2017) 18:45663. doi: $10.1038 /$ ni.3680

103. Cobey S, Hensley SE. Immune history and influenza virus susceptibility. Curr Opin Virol. (2017) 22:105-11. doi: 10.1016/j.coviro.2016.12.004

104. Krammer F. The human antibody response to influenza A virus infection and vaccination. Nat Rev Immunol. (2019) 19:383-97. doi: 10.1038/s41577-019-0143-6
105. Zaman K, Roy E, Arifeen SE, Rahman M, Raqib R, Wilson E, et al. Effectiveness of maternal influenza immunization in mothers and infants. N Engl J Med. (2008) 359:1555-64. doi: 10.1056/NEJMoa0708630

106. Poehling KA, Szilagyi PG, Staat MA, Snively BM, Payne DC, Bridges $\mathrm{CB}$, et al. Impact of maternal immunization on influenza hospitalizations in infants. Am J Obstet Gynecol. (2011) 204:S141-8. doi: 10.1016/j.ajog.2011.02.042

107. Nunes MC, Cutland CL, Jones S, Hugo A, Madimabe R, Simoes EA, et al. Duration of infant protection against influenza illness conferred by maternal immunization: secondary analysis of a randomized clinical trial. JAMA Pediatr. (2016) 170:840-7. doi: 10.1001/jamapediatrics.2016.0921

108. Tapia MD, Sow SO, Tamboura B, Teguete I, Pasetti MF, Kodio M, et al. Maternal immunisation with trivalent inactivated influenza vaccine for prevention of influenza in infants in Mali: a prospective, active-controlled, observer-blind, randomised phase 4 trial. Lancet Infect Dis. (2016) 16:102635. doi: 10.1016/S1473-3099(16)30054-8

109. Groothuis JR, Levin MJ, Rabalais GP, Meiklejohn G, Lauer BA. Immunization of high-risk infants younger than 18 months of age with split-product influenza vaccine. Pediatrics. (1991) 87:823-8.

110. Halasa NB, Gerber MA, Chen Q, Wright PF, Edwards KM. Safety and immunogenicity of trivalent inactivated influenza vaccine in infants. J Infect Dis. (2008) 197:1448-54. doi: 10.1086/587643

111. Diebold SS, Kaisho T, Hemmi H, Akira S, Reis e S. Innate antiviral responses by means of TLR7-mediated recognition of single-stranded RNA. Science. (2004) 303:1529-31. doi: 10.1126/science.1093616

112. Heil F, Hemmi H, Hochrein H, Ampenberger F, Kirschning C, Akira S, et al. Species-specific recognition of single-stranded RNA via toll-like receptor 7 and 8. Science. (2004) 303:1526-9. doi: 10.1126/science.1093620

113. Philbin VJ, Dowling DJ, Gallington LC, Cortes G, Tan Z, Suter EE, et al. Imidazoquinoline Toll-like receptor 8 agonists activate human newborn monocytes and dendritic cells through adenosine-refractory and caspase-1-dependent pathways. J Allergy Clin Immunol. (2012) 130:195204.e9. doi: 10.1016/j.jaci.2012.02.042

114. Levy O, Coughlin M, Cronstein BN, Roy RM, Desai A, Wessels MR. The adenosine system selectively inhibits TLR-mediated TNFalpha production in the human newborn. J Immunol. (2006) 177:195666. doi: 10.4049/jimmunol.177.3.1956

115. Holbrook BC, D’Agostino RB Jr, Tyler Aycock S, Jorgensen MJ, Hadimani $\mathrm{MB}$, Bruce King $\mathrm{S}$, et al. Adjuvanting an inactivated influenza vaccine with conjugated R848 improves the level of antibody present at 6months in a nonhuman primate neonate model. Vaccine. (2017) 35:613742. doi: 10.1016/j.vaccine.2017.09.054

116. Holbrook BC, Kim JR, Blevins LK, Jorgensen MJ, Kock ND, D’Agostino $\mathrm{RB}$ Jr, et al. A novel R848-conjugated inactivated influenza virus vaccine is efficacious and safe in a neonate nonhuman primate model. J Immunol. (2016) 197:555-64. doi: 10.4049/jimmunol.1600497

117. McCarron M, Reen DJ. Activated human neonatal CD8 ${ }^{+} \mathrm{T}$ cells are subject to immunomodulation by direct TLR2 or TLR5 stimulation. J Immunol. (2009) 182:55-62. doi: 10.4049/jimmunol.182.1.55

118. Levy O, Suter EE, Miller RL, Wessels MR. Unique efficacy of Toll-like receptor 8 agonists in activating human neonatal antigen-presenting cells. Blood. (2006) 108:1284-90. doi: 10.1182/blood-2005-12-4821

119. Warger T, Osterloh P, Rechtsteiner G, Fassbender M, Heib V, Schmid B, et al. Synergistic activation of dendritic cells by combined Toll-like receptor ligation induces superior CTL responses in vivo. Blood. (2006) 108:54450. doi: 10.1182/blood-2005-10-4015

120. Randhawa AK, Hawn TR. Toll-like receptors: their roles in bacterial recognition and respiratory infections. Expert Rev Anti Infect Ther. (2008) 6:479-95. doi: 10.1586/14787210.6.4.479

121. Willis E, Pardi N, Parkhouse K, Mui BL, Tam YK, Weissman D, et al. Nucleoside-modified mRNA vaccination partially overcomes maternal antibody inhibition of de novo immune responses in mice. Sci Transl Med. (2020) 12. doi: 10.1126/scitranslmed.aav 5701

122. Pardi N, Hogan MJ, Naradikian MS, Parkhouse K, Cain DW, Jones L, et al. Nucleoside-modified mRNA vaccines induce potent $\mathrm{T}$ follicular helper and germinal center B cell responses. J Exp Med. (2018) 215:157188. doi: $10.1084 /$ jem. 20171450 
123. Vono M, Eberhardt CS, Mohr E, Auderset F, Christensen D, Schmolke $\mathrm{M}$, et al. Overcoming the neonatal limitations of inducing germinal centers through liposome-based adjuvants including C-type lectin agonists trehalose dibehenate or curdlan. Front Immunol. (2018) 9:381. doi: 10.3389/fimmu.2018.00381

124. Lu X, Nagata M, Yamasaki S. Mincle: 20 years of a versatile sensor of insults. Int Immunol. (2018) 30:233-9. doi: 10.1093/intimm/dxy028

125. Granoff DM, McHugh YE, Raff HV, Mokatrin AS, Van Nest GA. MF59 adjuvant enhances antibody responses of infant baboons immunized with Haemophilus influenzae type b and Neisseria meningitidis group C oligosaccharide-CRM197 conjugate vaccine. Infect Immun. (1997) 65:17105. doi: 10.1128/IAI.65.5.1710-1715.1997

126. Mastelic Gavillet B, Eberhardt CS, Auderset F, Castellino F, Seubert A, Tregoning JS, et al. MF59 mediates its B cell adjuvanticity by promoting $\mathrm{T}$ follicular helper cells and thus germinal center responses in adult and early life. J Immunol. (2015) 194:4836-45. doi: 10.4049/jimmunol.1402071

127. McGuire EP, Fong Y, Toote C, Cunningham CK, McFarland EJ, Borkowsky W, et al. HIV exposed infants vaccinated with a MF59/rgp120 vaccine have higher magnitude anti-V1V2 IgG responses than adults immunized with the same vaccine. J Virol. (2017) 92:e01070-17. doi: 10.1128/JVI.01070-17

128. Pihlgren M, Tougne C, Bozzotti P, Fulurija A, Duchosal MA, Lambert $\mathrm{PH}$, et al. Unresponsiveness to lymphoid-mediated signals at the neonatal follicular dendritic cell precursor level contributes to delayed germinal center induction and limitations of neonatal antibody responses to T-dependent antigens. J Immunol. (2003) 170:2824-32. doi: 10.4049/jimmunol.170.6.2824

129. Bjarnarson SP, Adarna BC, Benonisson H, Del Giudice G, Jonsdottir I. The adjuvant LT-K63 can restore delayed maturation of follicular dendritic cells and poor persistence of both protein- and polysaccharide-specific antibody-secreting cells in neonatal mice. J Immunol. (2012) 189:126573. doi: 10.4049/jimmunol.1200761

130. Aradottir Pind AA, Dubik M, Thorsdottir S, Meinke A, Harandi $\mathrm{AM}$, Holmgren $\mathrm{J}$, et al. Adjuvants enhance the induction of germinal center and antibody secreting cells in spleen and their persistence in bone marrow of neonatal mice. Front Immunol. (2019) 10:2214. doi: 10.3389/fimmu.2019.02214

131. Henry C, Palm AE, Krammer F, Wilson PC. From original antigenic sin to the universal influenza virus vaccine. Trends Immunol. (2018) 39:709. doi: 10.1016/j.it.2017.08.003

132. Krammer F, Garcia-Sastre A, Palese P. Is it possible to develop a "universal" influenza virus vaccine? Potential target antigens and critical aspects for a universal influenza vaccine. Cold Spring Harb Perspect Biol. (2018) 10:a028845. doi: 10.1101/cshperspect.a0 28845

133. Boudreau CM, Alter G. Extra-neutralizing FcR-mediated antibody functions for a universal influenza vaccine. Front Immunol. (2019) 10:440. doi: 10.3389/fimmu.2019.00440

134. Coughlan L, Palese P. Overcoming barriers in the path to a universal influenza virus vaccine. Cell Host Microbe. (2018) 24:18-24. doi: 10.1016/j.chom.2018.06.016

135. Yassine HM, Boyington JC, McTamney PM, Wei CJ, Kanekiyo M, Kong WP, et al. Hemagglutinin-stem nanoparticles generate heterosubtypic influenza protection. Nat Med. (2015) 21:1065-70. doi: 10.1038/nm. 3927

Conflict of Interest: The author declares that the research was conducted in the absence of any commercial or financial relationships that could be construed as a potential conflict of interest.

Copyright (c) 2020 Alexander-Miller. This is an open-access article distributed under the terms of the Creative Commons Attribution License (CC BY). The use, distribution or reproduction in other forums is permitted, provided the original author(s) and the copyright owner(s) are credited and that the original publication in this journal is cited, in accordance with accepted academic practice. No use, distribution or reproduction is permitted which does not comply with these terms. 